\title{
DEVELOPMENT OF ANALYSIS METHODOLOGY USING PROTON INDUCED X-RAY EMISSION (PIXE) AS A COMPLEMENTARY TECHNIQUE TO DETERMINE TRACE ELEMENTS IN ENVIRONMENTAL MATRICES
}

\author{
Antoaneta Ene $e^{\mathrm{a}, \mathrm{b}, *}$, Ana Pantelică ${ }^{\mathrm{c}}$, Sorina-Simona Arbanaș (Moraru) ${ }^{\mathrm{a}, \mathrm{b}}$, Violeta \\ Pintilie $^{\mathrm{a}, \mathrm{b}}$, Florin Sloatăăb, Florina Cristiana Căpriță ${ }^{\mathrm{a}, \mathrm{b}}$, Mihai Straticiuc ${ }^{\mathrm{c}}$, Dragoș \\ Mirea $^{c}$, Andreea Şerban ${ }^{c}$, Claudia Stihi ${ }^{d}$, Marina Frontasyeva ${ }^{e}$, \\ Oleg Bogdevich ${ }^{\mathrm{f}}$, Elena Culighin ${ }^{\mathrm{f}}$ \\ a "Dunarea de Jos" University of Galati, Doctoral School of Mechanical and Industrial Engineering, 47 \\ Domneasca St., RO-800008, Galati, Romania \\ ${ }^{b} I N P O L D E$ interdisciplinary research center, ReForm-UDJG Platform, Faculty of Sciences and Environment, \\ Chemistry, Physics and Environment Department, Dunarea de Jos University of Galati, 111 Domneasca St., \\ 800201 Galati, Romania \\ ${ }^{c}$ Horia Hulubei National Institute for $R \& D$ in Physics and Nuclear Engineering, Bucharest-Magurele, Romania \\ ${ }^{d}$ Valahia University of Targoviste, Targoviste, Romania \\ e Joint Institute for Nuclear Research, Dubna, Russian Federation \\ ${ }^{f}$ Institute of Geology and Seismology, Chisinau, Republic of Moldova
}

*Corresponding author: aene@ugal.ro

\begin{abstract}
This article presents the methodology of analysis of industrial and environmental materials using Particle Induced $\mathrm{X}$-ray Emission (PIXE) technique. The application of thick target PIXE technique using a $3 \mathrm{MeV}$ proton beam at 3 MV Tandetron at Horia Hulubei National Institute for R\&D in Physics and Nuclear Engineering (IFIN-HH), Romania, in industrial and environmental complex studies proved to be very useful for the identification of a large series of trace elements, some of them being toxic for living organisms and humans and others contributing to the elemental cycling in natural environments. The main elements determined by PIXE are $\mathrm{K}, \mathrm{Ca}, \mathrm{Ti}, \mathrm{V}, \mathrm{Cr}, \mathrm{Mn}, \mathrm{Fe}$, $\mathrm{Ni}, \mathrm{Cu}, \mathrm{Zn}, \mathrm{As}, \mathrm{Br}, \mathrm{Rb}, \mathrm{Sr}$ and Pb, using High Purity Germanium (HPGe) GDP-05145 (BSI) type detector of 20 $\mathrm{mm}^{2}$ surface, $8 \mathrm{~mm}$ thickness. In addition, $\mathrm{Na}, \mathrm{Mg}, \mathrm{Al}, \mathrm{Si}, \mathrm{P}, \mathrm{S}$, and $\mathrm{Cl}$ could be determined using external beam PIXE with X-123 SDD Fast Amptek silicon detector of $25 \mathrm{~mm}^{2}$ surface, $500 \mu \mathrm{m}$ thickness. PIXE technique successfully complements other atomic and nuclear techniques, such as: energy dispersive X-ray fluorescence (ED-XRF), instrumental neutron activation analysis (INAA), inductively-coupled plasma mass spectrometry (ICPMS), atomic absorption spectrometry (AAS) and ion beam technique particle-induced gamma-ray emission (PIGE). A discussion is made regarding the suitability of PIXE technique to be further used in studies related to soil-crop toxic metal transfer in an agroecosystem, as well as heavy metals biosorbtion from industrial wastewater, for the investigation of level of contamination with metals and toxicants occurrence in environmental factors and human health risk assessment. The paper was presented at the Scientific Conference of the Doctoral School of "Dunarea de Jos" University of Galati (SCDS-UDJG), 7th edition, Galati, Romania, 13-14 June, 2019.
\end{abstract}

Keywords: trace elements, IBA techniques, PIXE, PIGE, RBS, soils, plants, algae, fish, industrial wastes.

\section{INTRODUCTION}

Heavy metals and toxic elements are widespread in all the environmental compartments due to existence of natural and anthropogenic sources and can be transferred in food chains through bioaccumulation and bioconcentration. Plants and algae are useful biological indicator organisms, which 
could be employed in monitoring of pollution with heavy metals and trace elements in terrestrial and aquatic ecosystems [1].

Metallic trace elements, or micronutrients, play an important role in the metabolic pathways during the growth and development of plants. Food contamination is an increasingly important public health issue and governments all over the world are intensifying their efforts to improve food safety [2]. Using contaminated agricultural soils around various industries for cultivation of edible crops for consumption may result in chronic hazards to human health [3-5].

Dispersion of metals through wastewater release in surface waters and environment is a pressing issue nowadays and several proposals for removing these toxic elements from industrial effluents have been formulated by many researchers, marine algae being a suitable removal material $[6,7]$.

Ion Beam Analytical (IBA) techniques such as particle-induced X-ray emission (PIXE) [1-3,8-12] and particle-induced gamma-ray emission (PIGE) [1,3,10-12,14], have been extensively employed in the life sciences, in particular environmental field, due to their capabilities to measure a wide range of elements with an adequate sensitivity. IBA techniques represent a cluster of atomic and nuclear analytical techniques (Fig.1) that make use of ion beams for study of structures and composition of samples belonging to various classes of materials. PIXE is based on the ionization of atomic inner shells of a target sample by a beam of projectile charged particles of " $p$ " type (protons, in particular) entering the target, followed by emission of the characteristic X-rays. PIGE is able to determine especially light elements in a sample (such as $\mathrm{Li}, \mathrm{B}, \mathrm{F}, \mathrm{Na}, \mathrm{Mg}, \mathrm{Al}, \mathrm{Si}, \mathrm{P}, \mathrm{S}$, and $\mathrm{Cl}$ ), besides some heavier elements (e.g. Ti, $\mathrm{Cr}, \mathrm{Mn}, \mathrm{Fe}, \mathrm{Co}, \mathrm{Cu}$ ), based on detection of prompt gamma rays resulted from (p,p' $\gamma),(\mathrm{p}, \gamma)$, $(p, \alpha \gamma)$ or $(p, n \gamma)$ nuclear reactions of the incident particles "p" on target nuclei [10-14]. In Fig.1 there are presented the principles of atomic and nuclear excitations which stay at the basis of the main IBA techniques PIXE, PIGE, Rutherford Backscattering Spectrometry (RBS), and Nuclear Reaction Analysis (NRA) [10].

PIXE proved to be a very useful analytical technique in environmental monitoring and interdisciplinary studies. It was applied in the last decade for various applications by our research team using a $3 \mathrm{MeV}$ proton beam, generated by the $9 \mathrm{MV}$ FN Van de Graff Tandem, as well as $3 \mathrm{MV}$ Tandetron accelerators of the Horia Hulubei National Institute of Physics and Nuclear Engineering (IFIN-HH) to determine elemental concentrations in different iron and steel materials, as well as environmental and biological samples [1,2,8-13]. PIXE was often used as a complementary technique to other multielemental nuclear and atomic techniques, such as instrumental neutron activation analysis (INAA) $[3,9,12,15,16]$, energy dispersive X-ray fluorescence (ED-XRF) [15,16], PIGE [1,11-14] and RBS [17], as well as the destructive techniques inductively-coupled plasma mass spectrometry (ICPMS) [1,16] and atomic absorption spectrometry (AAS) [1].

The aim of the present proposal is to investigate the capabilities of PIXE for the multi-elemental analysis of industrial (sludge, waste materials) and environmental samples (soils, cultivated plants, algae) in order to assess the level of pollution with metals and toxic elements, element transfer in biota, bioaccumulation and bioconcentration of pollutants in plant tissues.

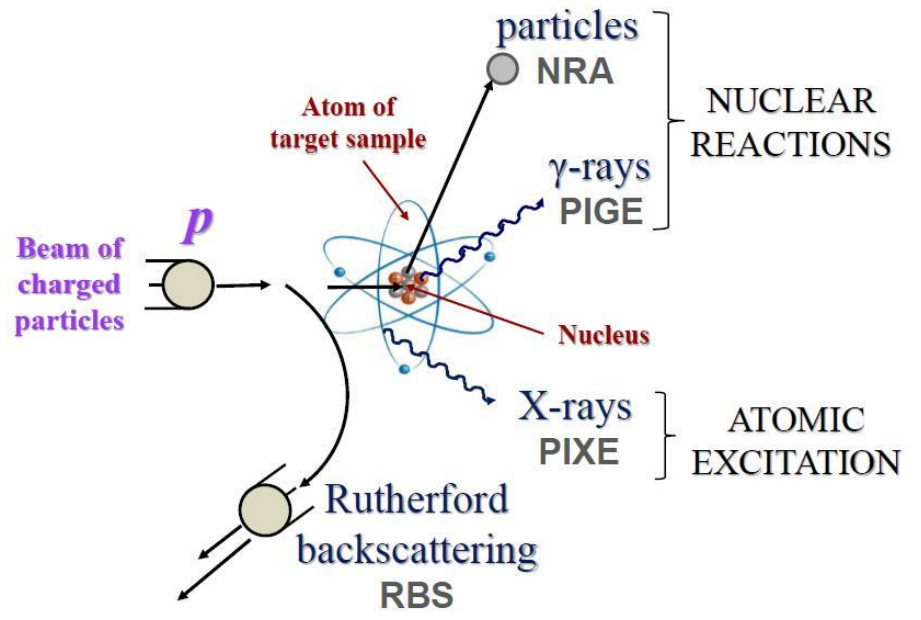

Fig. 1. Scheme of atomic and nuclear excitation by a charged particle beam 


\section{EXPERIMENTAL}

\subsection{Sample collection and preparation}

The soil samples were collected in the vicinity of the industrial platform in the western part of Galati town, in the SE region of Romania, where a steel industrial complex has been operating for more than 50 years. The cultivated plant materials to be investigated were sampled from the same sites. The hydro-physical and mineralogical characteristics of parent soils were determined by established accredited methods at "Dunarea de Jos" University of Galati (UDJG) [18,19]. Edible plant sections, used both for human and animal feed, were separated and prepared using standard methods. Some contaminated soils and sands were sampled by INPOLDE research team at UDJG from industrial enterprises in Romania, as waste materials.

For this experiment five different algae species from Black Sea, Romania, were used [7]: Ulva rigida, Punctaria latifolia, Pyropia leucosticta, Callithamnion corymbosum and Cladophora vagabunda.

Environmental samples to be investigated by IBA techniques were dried, ground, and then pressed as pellets of $1 \mathrm{~mm}$ thickness and $1 \mathrm{~cm}$ diameter using hydraulic press. Appropriate comparator standards were similarly prepared as pellets (thick targets) (Fig. 2).

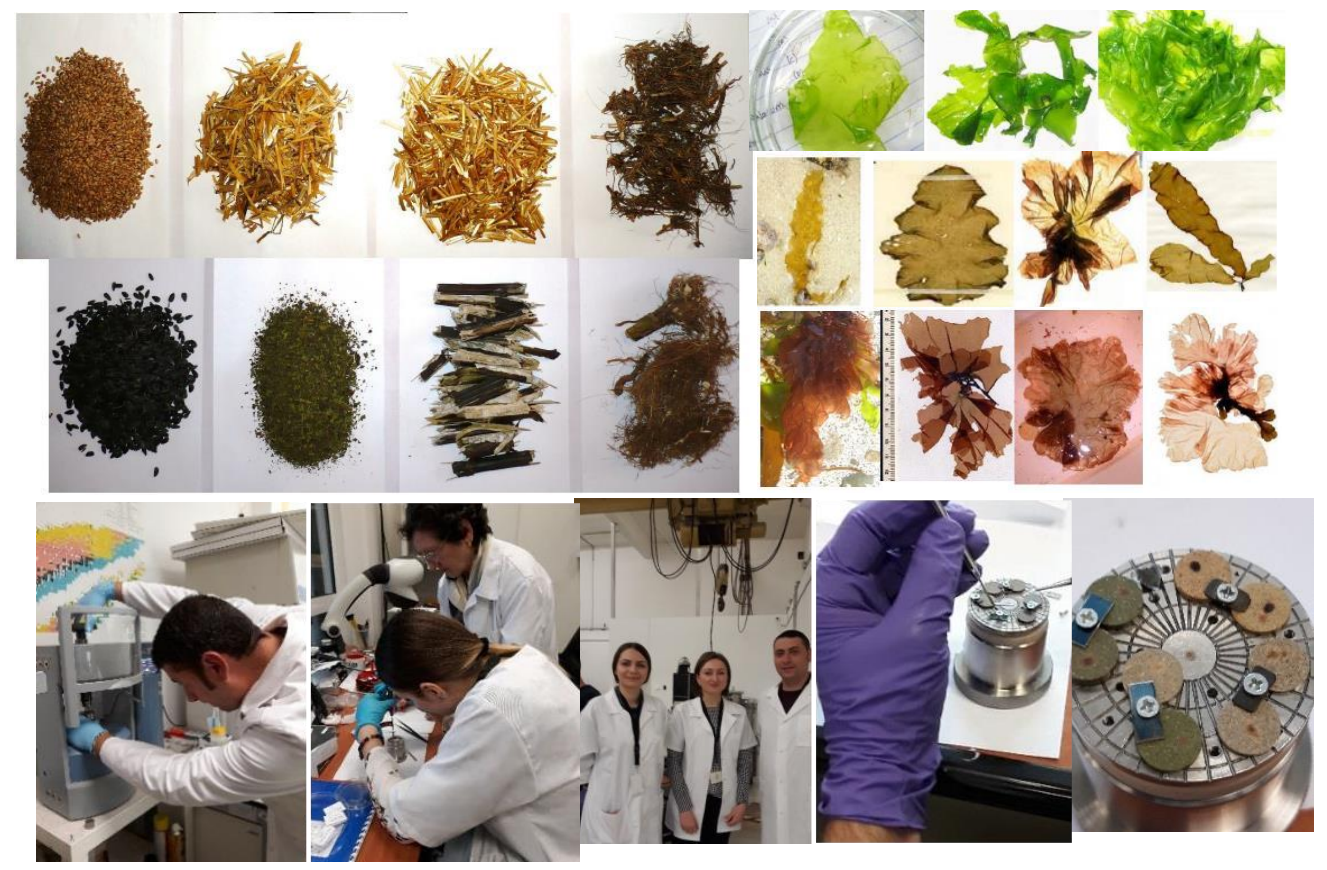

Fig. 2. Preparation of industrial and environmental samples for analysis by PIXE and IBA techniques

\subsection{Ion Beam Analysis (IBA)}

PIXE, PIGE and RBS analytical techniques were applied at the 3 MV Tandetron of IFIN-HH using a dedicated IBA reaction chamber (Fig.3). PIXE and PIGE measurements were performed using a $3 \mathrm{MeV}$ proton beam in vacuum, normal to the target. In addition, external beam PIXE was employed for some of the samples. The X-ray and gamma-ray detectors were placed at $45^{\circ}$ with respect to the target and beam direction.

The beam intensity was kept in the range $1.4-3 \mathrm{nA}$ (collection time of $0.5-1 \mathrm{~h}$ ) to maintain a dead time lower than $10 \%$, which implies low pile-up effects. Particle beam energy, beam charge on the target, as well as the X-ray, gamma-ray and scattered particle spectra were concomitantly registered. The spectra were processed off-line using specific software programmes. 


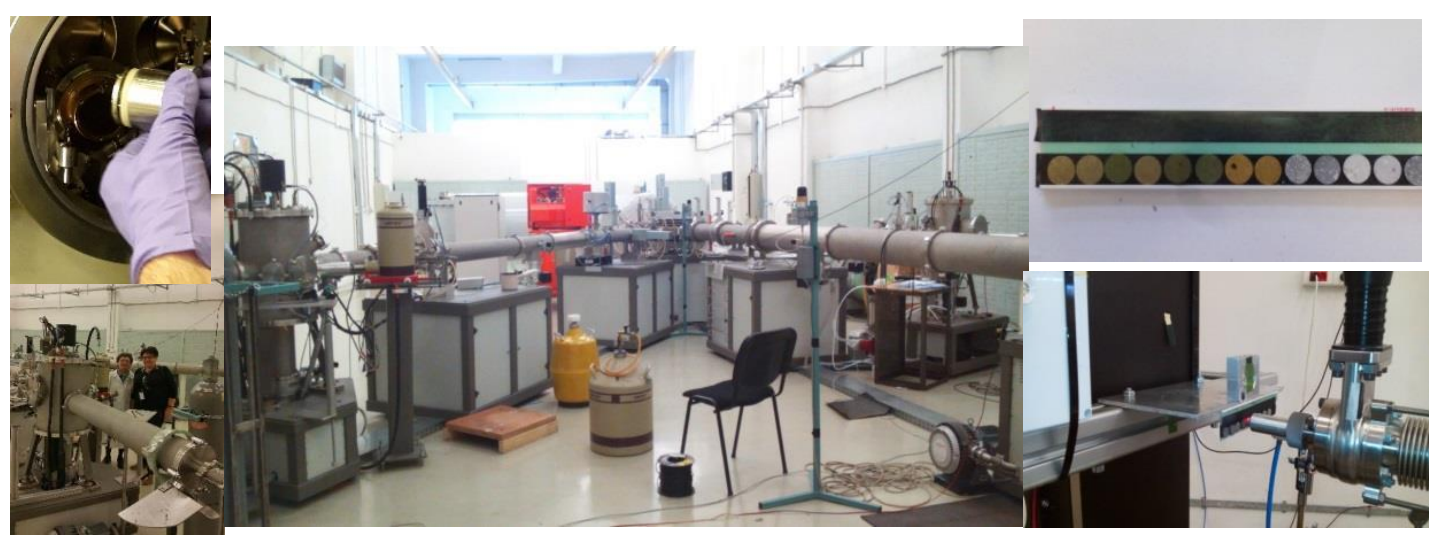

Fig. 3. Experimental set up for IBA analyses at 3 MV Tandetron of IFIN-HH: PIXE, PIGE, RBS - in vacuum (left side), PIXE - external beam (right side).

For PIXE analysis, GUPIXWIN (Guelph PIXE) programme was used. Element concentrations determined were normalized to $100 \%$ total mass. Light major elements invisible in the X-ray spectra, e.g. $\mathrm{O}$ and $\mathrm{C}$, were taken in account in the GUPIX calculation.

For PIGE, a relative method for quantitative analysis was used, based on comparator standards of certified elemental concentrations/mass fractions of similar matrix with the investigated samples, e.g. IAEA-356 and IAEA SD-M-2/TM marine sediments, IAEA MA-M-2/TM and IAEA MA-B-3 mussel and fish tissue, respectively, INCT-TL-1 (Tea Leves), INCT-OBTL-5 (Oriental Basma Tobacco Leaves). High purity chemical compounds, e.g. $\mathrm{NaCl}, \mathrm{MgO}, \mathrm{CaF}_{2}$, and $\mathrm{Fe}_{2} \mathrm{P}$, as well as $\mathrm{Al}$ foil were also considered to determine $\mathrm{Na}, \mathrm{Cl}, \mathrm{Mg}, \mathrm{F}, \mathrm{Fe}, \mathrm{P}$, and $\mathrm{Al}$. Stopping powers of protons in samples and comparator standards could be calculated using SRIM software. Sample matrix (major elemental content) was assessed by RBS for light elements.

For RBS, the backscattered proton beam spectra were processed using RUMP programme. Hydrogen content could be indirectly determined for a better agreement between experimental spectrum and RUMP simulation.

A high purity germanium (HPGe) detector (GDP-05145 (BSI) type, $20 \mathrm{~mm}^{2}$ surface and $8 \mathrm{~mm}$ thickness) was used for internal beam PIXE technique in vacuum. External beam PIXE employed an Xray silicon detector SDD Amptek $\left(25 \mathrm{~mm}^{2}\right.$ surface, $500 \mu \mathrm{m}$ thickness, Be window of 0.5 mil) with 140 $\mathrm{eV}$ energy resolution at $5.9 \mathrm{keV}$.

For PIGE, an HPGe type Ortec detector (GEM10P4-70) with $1.75 \mathrm{keV}$ resolution at $1332 \mathrm{keV}$ of ${ }^{60} \mathrm{Co}$ and $10 \%$ relative efficiency was used.

For RBS, a passivated ion implanted silicon detector with energy resolution of $16 \mathrm{keV}$ was employed. The detector was placed inside the reaction chamber at an angle of $165^{\circ}$ with respect to the incident beam and subtended a solid angle of $1.641 \mathrm{msr}$. To avoid the channeling effects, the sample suport was tilted $7^{\circ}$ relative to the beam direction.

\section{RESULTS AND DISCUSSION}

The elements determined by PIXE were $\mathrm{K}, \mathrm{Ca}, \mathrm{Ti}, \mathrm{V}, \mathrm{Cr}, \mathrm{Mn}, \mathrm{Fe}, \mathrm{Ni}, \mathrm{Cu}, \mathrm{Zn}, \mathrm{As}, \mathrm{Br}, \mathrm{Rb}, \mathrm{Sr}$ and $\mathrm{Pb}$. In addition, $\mathrm{Na}, \mathrm{Mg}, \mathrm{Al}, \mathrm{Si}, \mathrm{P}, \mathrm{S}$, and $\mathrm{Cl}$ could be determined using external beam PIXE. The elements investigated by PIGE were $\mathrm{Li}, \mathrm{B}, \mathrm{F}, \mathrm{Na}, \mathrm{Mg}, \mathrm{Al}, \mathrm{Si}$, and $\mathrm{P}$. The elements determined by RBS were $\mathrm{C}, \mathrm{N}, \mathrm{O}, \mathrm{Si}(\mathrm{P}, \mathrm{S}, \mathrm{Cl})$ and $\mathrm{K}(\mathrm{Ca})$.

Examples of PIXE, PIGE and RBS spectra measured by our team at the $3 \mathrm{MV}$ Tandetron accelerator in IFIN-HH for thick targets of environmental and biological samples are given in Figs. 46 , demonstrating the capabilities of the three IBA techniques and the possibility to combine them for better assessment of bioaccumulation of metals and trace elements.

Nuclear reactions of (p,p' $\gamma$ ) type on ${ }^{18} \mathrm{~F},{ }^{23} \mathrm{Na},{ }^{24,25} \mathrm{Mg},{ }^{27} \mathrm{Al},{ }^{28,29} \mathrm{Si},{ }^{31} \mathrm{P}$, and ${ }^{56} \mathrm{Fe}$ nuclides, and (p, $\alpha \gamma)$ type on ${ }^{23} \mathrm{Na}$ and ${ }^{31} \mathrm{P}$ nuclides, and $(\mathrm{p}, \mathrm{n} \gamma)$ type on ${ }^{48} \mathrm{Ca}$, as well as characteristic gamma lines are noted on the PIGE spectrum. 
PIXE analytical technique with $3 \mathrm{MeV}$ protons is most sensitive for middle- $\mathrm{Z}$ elements, due to the relatively high ionization cross-sections, lower intensity background traceable to the bremsstrahlung of secondary electrons, and high detection efficiency. Its sensitivity is decreasing both for lower- and higher-Z elements. For heavy elements, characterized by smaller ionization cross-sections and lower detection efficiency, PIXE can be completed by neutron activation analysis (NAA) [9,12]. Elements with atomic numbers lower than 15 can be analysed with a good sensitivity by PIGE.
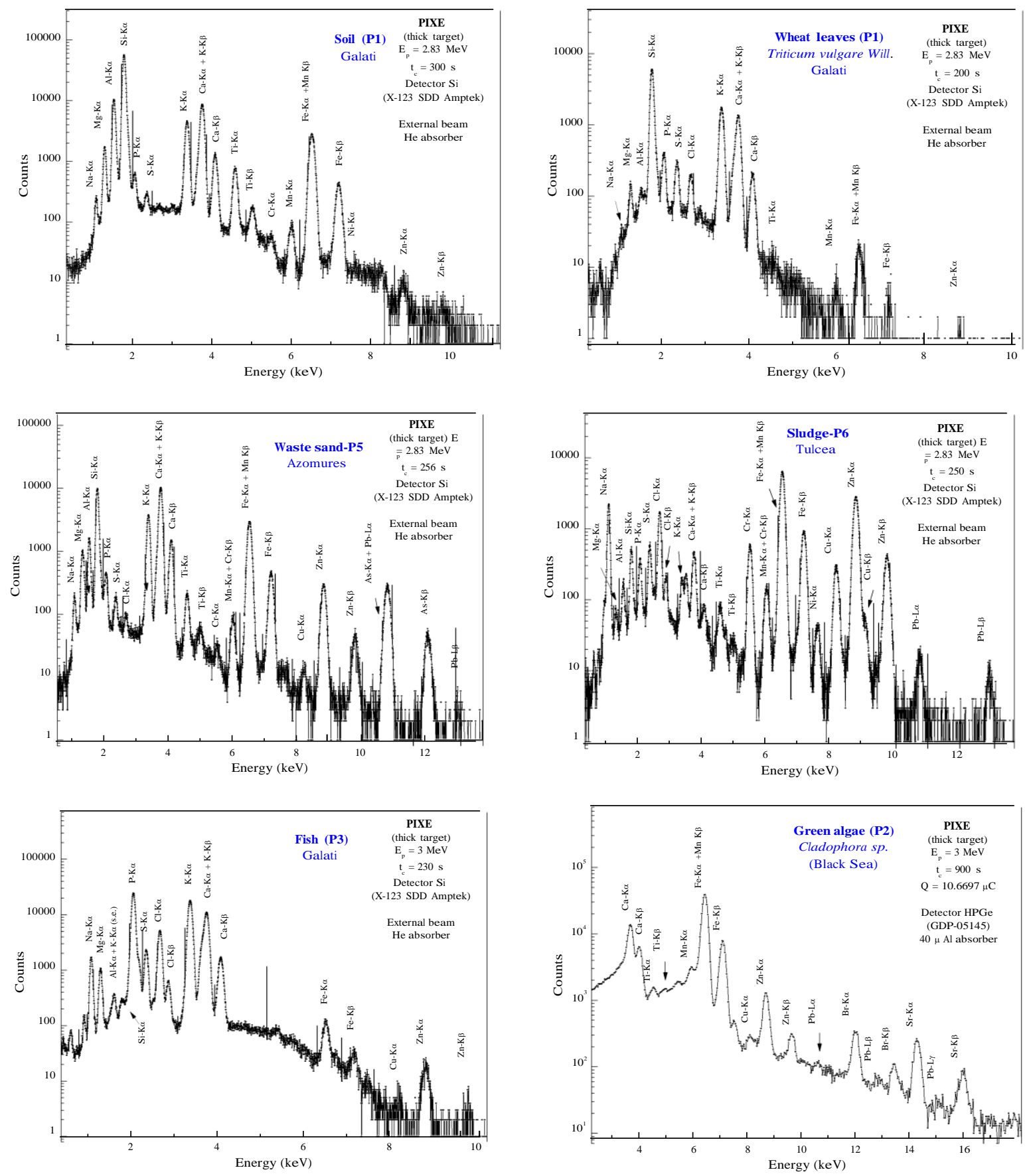

Fig. 4. PIXE spectra obtained at IFIN-HH for environmental and biological samples (soil, wheat leaves, waste sand, sludge, fish, algae). 

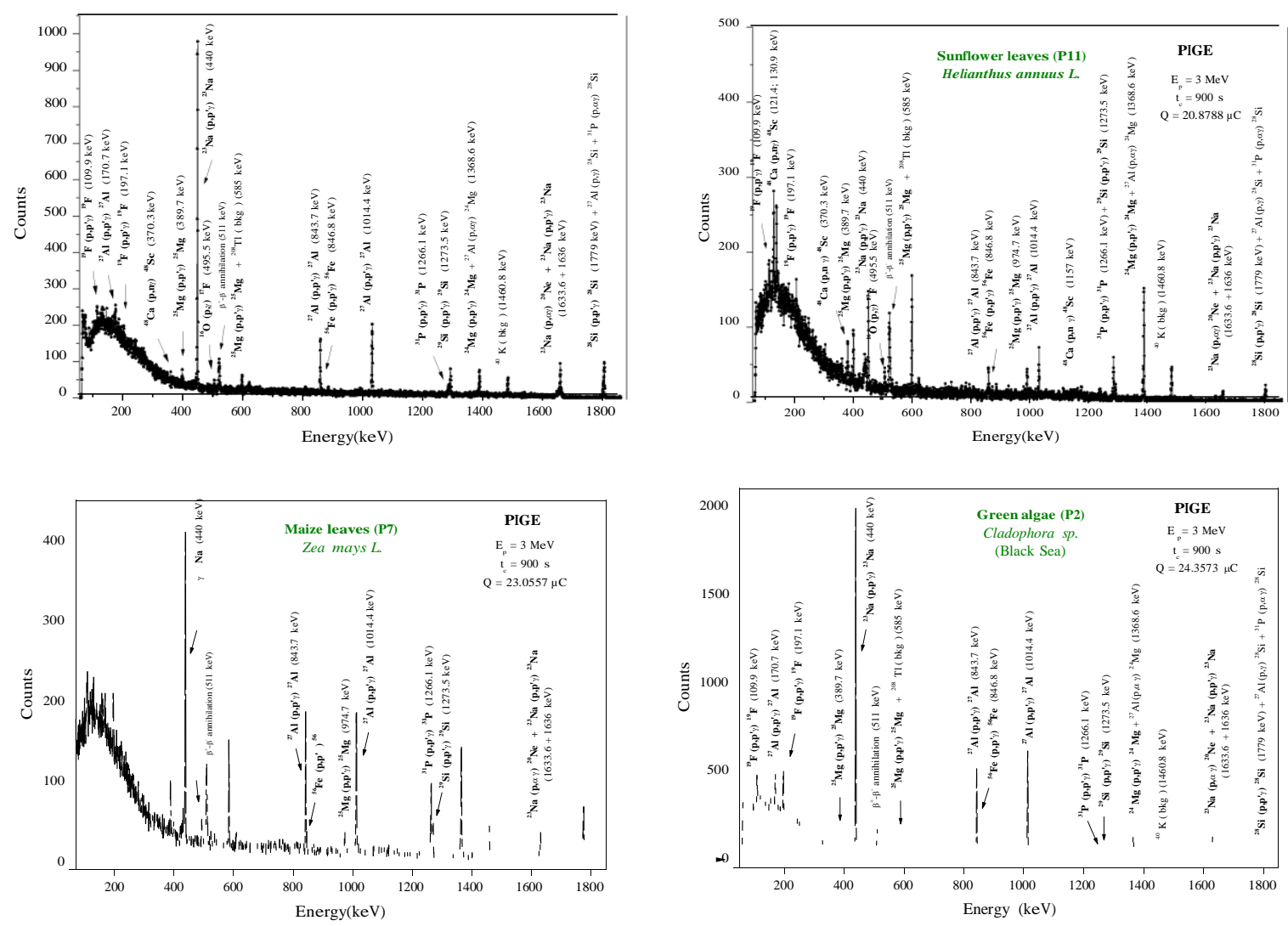

Fig. 5. PIGE spectra obtained at IFIN-HH for plant tissues (wheat, sunflower and maize leaves, green algae).

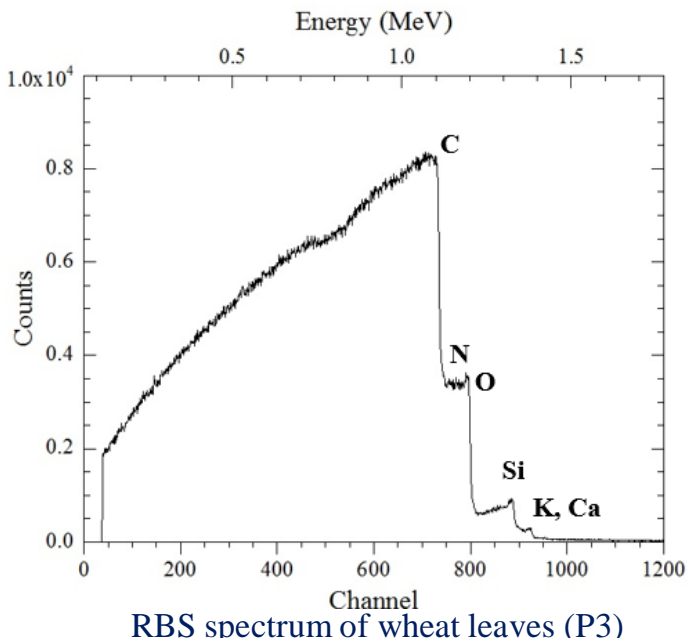

RBS spectrum of wheat leaves (P3)

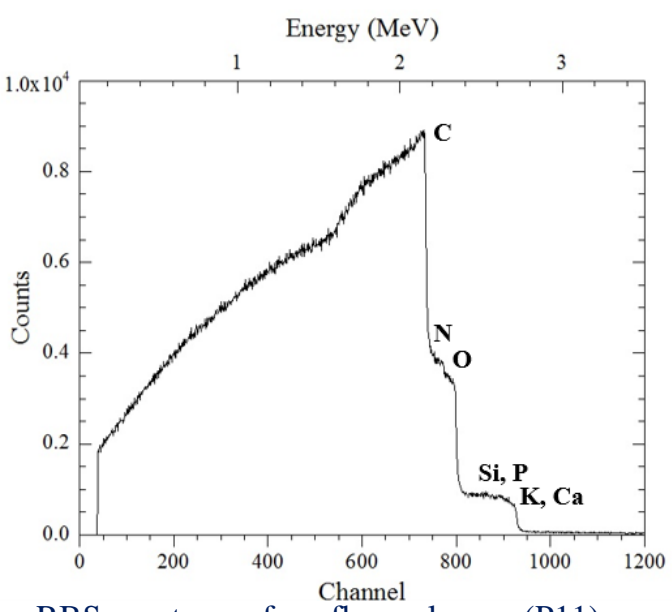

RBS spectrum of sunflower leaves (P11)

Fig. 6. RBS spectra obtained at IFIN-HH for wheat and sunflower leaves samples. 
Table 1. Detection limits (LOD) of nuclear and atomic techniques on selected environmental samples collected at Galati, d.w. (dry weight); LOQ - Quantification limit for AAS, Flame (F) and Graphite Furnace (GF).

\begin{tabular}{|c|c|c|c|c|c|c|}
\hline \multirow[b]{2}{*}{ Elem. } & \multicolumn{2}{|c|}{$\underset{\left(\mathrm{mg} \cdot \mathrm{kg}^{-1}\right)}{\mathrm{PIXE}}$} & \multirow{2}{*}{$\frac{\begin{array}{c}\mathrm{PIGE} \\
\left(\mathrm{g} \cdot \mathrm{kg}^{-1}\right)\end{array}}{\begin{array}{c}\text { Soil (P3)/ } \\
\text { Wheat leaves } \\
(\mathrm{P} 3)\end{array}}$} & \multirow{2}{*}{$\begin{array}{c}\begin{array}{c}\text { AAS (F) } \\
\left(\mathrm{mg}^{\mathrm{kg}} \mathrm{kg}^{-1}\right)\end{array} \\
\begin{array}{c}\text { Soil, sediment, } \\
\text { plant } \\
\text { LOD / LOQ }\end{array}\end{array}$} & \multirow{2}{*}{\begin{tabular}{|c|}
$\begin{array}{c}\text { AAS }(\mathrm{GF}) \\
\left(\mu \mathrm{g} \cdot \mathrm{kg}^{-1}\right)\end{array}$ \\
$\begin{array}{c}\text { Soil, sediment, } \\
\text { plant } \\
\text { LOD / LOQ }\end{array}$ \\
\end{tabular}} & \multirow{2}{*}{\begin{tabular}{|c}
$\begin{array}{c}\text { INAA } \\
\left(\mathrm{mg} \cdot \mathrm{kg}^{-1}\right)\end{array}$ \\
$\begin{array}{c}\text { Tree leaves } \\
{[12]}\end{array}$
\end{tabular}} \\
\hline & $\begin{array}{c}\text { Soil } \\
\text { (P2 / P1-G12) }\end{array}$ & $\begin{array}{c}\text { Wheat leaves } \\
\text { (P3) / } \\
\text { Danube Fish } \\
\text { (P4) }\end{array}$ & & & & \\
\hline $\mathrm{Li}$ & & & $0.008 / 0.004$ & & & \\
\hline $\mathrm{B}$ & & & $0.90 / 0.35$ & & & \\
\hline $\mathrm{F}$ & & & $0.014 / 0.012$ & & & - \\
\hline $\mathrm{Na}$ & $251 / 275$ & $160 / 260$ & $0.035 / 0.017$ & & & $1.1 / 1.7^{\mathrm{a}}$ \\
\hline $\mathrm{Mg}$ & $63 / 81$ & $80 / 92$ & $1.70 / 1.10$ & & & $20^{\mathrm{a}}$ \\
\hline $\mathrm{Al}$ & $69 / 68$ & $27 / 55$ & $0.15 / 0.085$ & & & $2^{a}$ \\
\hline $\mathrm{Si}$ & $82 / 67$ & $11 / 35$ & $4.70 / 3.40$ & & & $9000^{a}$ \\
\hline $\mathrm{P}$ & $81 / 86$ & $9 / 24$ & $0.50 / 0.30$ & & & - \\
\hline$S$ & $57 / 68$ & $8 / 16$ & $80 / 40$ & & & - \\
\hline $\mathrm{Cl}$ & $57 / 68$ & $8 / 9$ & $2.90 / 1.35$ & & & $15^{\mathrm{a}}$ \\
\hline $\mathrm{K}$ & $102 / 104$ & $11 / 23$ & & & & $112 / 775^{a}$ \\
\hline $\mathrm{Ca}$ & $167 / 145$ & $25 / 106$ & $43 / 19$ & & & $250 / 111^{\mathrm{a}}$ \\
\hline $\mathrm{Ti}$ & $59 / 34$ & $10 / 67$ & $1.60 / 0.82$ & & & $90^{\mathrm{a}}$ \\
\hline$\overline{\mathrm{V}}$ & $107 / 145$ & $16 / 38$ & $3.60 / 1.85$ & & & $0.13^{\mathrm{a}}$ \\
\hline $\mathrm{Cr}$ & $41 / 38$ & $13 / 52$ & $3.50 / 1.62$ & $5.8 / 17.5$ & $10.8 / 36.3$ & $0.05 / 2.7^{\mathrm{a}}$ \\
\hline $\mathrm{Mn}$ & $31 / 38$ & $10 / 29$ & $0.86 / 0.53$ & $6.8 / 20.7$ & $9.1 / 30.4$ & $0.20^{\mathrm{a}}$ \\
\hline $\mathrm{Fe}$ & $38 / 40$ & $12 / 18$ & $5.30 / 2.55$ & $6.7 / 20$ & & $2.7 / 36^{\mathrm{a}}$ \\
\hline $\mathrm{Ni}$ & $47 / 96$ & $10 / 20$ & & $6.3 / 19.2$ & $116 / 386$ & $3.5 / 1.0^{\mathrm{a}}$ \\
\hline $\mathrm{Cu}$ & $54 / 65$ & $10 / 11$ & $10.0 / 5.5$ & $2.0 / 6.2$ & $25.8 / 85.8$ & $16^{\mathrm{b}}$ \\
\hline $\mathrm{Zn}$ & $24 / 35$ & $10 / 18$ & & $0.93 / 2.81$ & & $0.08 / 0.80^{\mathrm{a}}$ \\
\hline As & $33 / 55$ & $11 / 36$ & & & & $0.07 / 0.02^{\mathrm{a}}$ \\
\hline $\mathrm{Se}$ & $37 / 49$ & $12 / 23$ & & & & $0.06 / 0.09^{\mathrm{a}}$ \\
\hline $\mathrm{Br}$ & $42 / 69$ & $35 / 36$ & & & & $0.09 / 0.03^{\mathrm{a}}$ \\
\hline $\mathrm{Rb}$ & $64 / 94$ & $32 / 81$ & & & & $0.17 / 0.20^{\mathrm{a}}$ \\
\hline $\mathrm{Sr}$ & $96 / 129$ & $92 / 82$ & & & & $2.2 / 1.3^{\mathrm{a}}$ \\
\hline $\mathrm{Cd}$ & $46 / 64$ & $2 / 3$ & & $1.7 / 5.1$ & $0.38 / 1.9$ & $0.35 / 0.25^{\mathrm{a}}$ \\
\hline $\mathrm{Pb}$ & $53 / 55$ & $2 / 3$ & & $2.7 / 8.0$ & $73.8 / 225$ & \\
\hline
\end{tabular}

${ }^{\mathrm{a}}$ INAA at JINR Dubna (epithermal neutron flux); ${ }^{\mathrm{b}}$ INAA at IFIN-HH Bucharest (lichen sample) [16]. 
The environmental samples (soils, plant tissues, industrial wastes, wild vegetation, fish, algae) were also investigated using related validated techniques at partner institutions: UDJG - INPOLDE research center, Valahia University of Targoviste, Romania, Joint Institute of Nuclear Research (JINR) at Dubna, Russian Federation, and Institute of Geology and Seismology, Chisinau, Republic of Moldova. A comparison of detection limits of employed techniques is presented in Table 1.

Based on the results obtained in this work, future research directions could be drawn:

- ion beam analytical techniques (PIXE, PIGE, RBS) could be applied for the determination of major, minor and trace elements in selected biological samples collected in industrial areas, in order to assess the soil-plant transfer for different plant parts and the risk for human health;

- PIXE and PIGE ion beam analysis techniques are useful tools to study the toxic elements biosorption from industrial wastewater by marine macrophytes prolific species, in order to assess the algae element-specific bioconcentration capabilities.

Thus, combined PIXE and PIGE may bring highly relevant insights in engineering, environmental and biotechnology research. At the same time, the results obtained by IBA nuclear methods will be correlated with those made by applying atomic absorption spectrometry, already disseminated in several publications $[4,5]$.

\section{CONCLUSIONS}

The contamination of soil and water by various toxic and potential toxic elements is one of the major issues to be faced worldwide due to the threat posed by their migration in plants, animals and humans. The analysis of such elements requires great attention because the exceeding of the legislated levels in environmental compartments could have a negative impact on the ecosystem state and human health. It was therefore very important to study their levels in plants, soils, biomonitors and industrial wastes by employing an appropriate combination of high sensibility techniques, such as PIXE, PIGE and RBS besides XRF, AAS, ICP-MS and INAA.

Acknowledgements: The work was carried out in the frame of international projects and grants: JINRRomania; MIS ETC 1676-INPOLDE (2013-2015), Joint Operational Programme Romania-UkraineRepublic of Moldova 2007-2013; and BSB27-MONITOX (2018-2021), Joint Operational Programme Black Sea Basin 2014-2020. We thank the technical staff of IFIN-HH for supervising the beam experiments at 3MV Tandetron, approved by Programme Advisory Committee (PAC). The work of $\mathrm{PhD}$ student Sorina-Simona Arbanaș (Moraru) has been funded by the European Social Fund through the Sectoral Operational Programme Human Capital 2014-2020, through the Financial Agreement with the title „Burse pentru educaţia antreprenorială în rândul doctoranzilor şi cercetătorilor postdoctorat (Be Antreprenor!)" (in English: "Scholarships for entrepreneurial education among doctoral students and postdoctoral researchers (Be Entrepreneur!)", Contract no. 51680/09.07.2019 - SMIS code: 124539.

\section{References}

1. Ene A., Pantelica A., Arbanas (Moraru) S.S, Pintilie V., Sloata F., Caprita F. C., Straticiuc M., Mirea D., Serban A., Stihi C., Frontasyeva M., Bogdevich O., Culighin E., Development of analysis methodology using Proton Induced X-ray Emission (PIXE) as a complementary technique to determine trace elements in environmental matrices, Scientific Conference of the Doctoral School of "Dunarea de Jos" University of Galati (SCDS-UDJG), 7th edition, 13-14 June, Galati, Romania, Poster PP.2.4, Book of abstracts, 215, 2019.

2. Pantelica A., Ene A., Gugiu M., Ciortea C., Constantinescu O., PIXE analysis of some vegetal species, Rom. Reports Phys. 63(4), 997-1008, 2011.

3. Ene A., Stihi C., Pantelica A., Frontasyeva M., Moraru, S.S., Nuclear and related techniques used for the investigation of soil pollution and metal transfer in plants in industrial areas, 18th International Balkan Workshop on Applied Physics and Materials Science (IBWAP 2018), 10-13 July, Constanta, Romania, Poster S3.P12, Book of abstracts, Ovidius University Press, Constanta, 120, 2018. 
4. Ene A., Moraru S.S., Moraru D.I., Assessment of bioaccumulation of heavy metals in sunflower cultivated in the agricultural area next to steel industry, ISI Proceedings of the 19th International Multidisciplinary Scientific GeoConference (SGEM 2019), 19 (3.2), 25-32, 2019, doi: 10.5593/sgem2019/3.2/S13.004.

5. Arbanas (Moraru) S.S., Ene A., Moraru D.I., Contamination level of Triticum vulgare L. cultivated on soils around a metallurgical area in Galati, Romania, Annals Dunarea de Jos Univ. Galati, Fascicle II, Year XI (XLII), 1-9, 2019.

6. Caprita F.C., Ene A., Valorification directions for marine algae, Annals Dunarea de Jos Univ. Galati, Fascicle II, Year XI (XLII), 10-18, 2019.

7. Caprita F.C., Ene A., Biosorption of heavy metals from the metallurgical industry wastewater by macroalgae, AIP Conference Proceedings (in press), TIM 19 Physics Conference, Timisoara, Romania, 29-31 May 2019, paper 21, 2019.

8. Ene A., Popescu I.V., Stihi C., Gheboianu A., Pantelica A., Petre C., PIXE analysis of multielemental samples, Rom. Journ. Phys. 55(7-8), 806-814, 2010.

9. Ene A., Pantelica A., Tehnici analitice atomice şi nucleare utilizate în monitorizarea mediului (in English: Atomic and nuclear analytical techniques used in environmental monitoring), Galati University Press, Galati, 2011.

10. Ene A., Tehnici radiometrice de analiză și control (in English: Radiometric techniques used for analysis and control), Editura Fundatiei Universitare Dunarea de Jos din Galati, Galati, 2006.

11. Ene A., Pantelica A., Ghita D.G., Mitu A., PIXE-PIGE techniques used in environmental studies, 16th International Balkan Workshop on Applied Physics and Materials Science (IBWAP 2016), 79 July 2016, Constanta, Romania, Poster S3P02, Book of Abstracts, Ovidius University Press, Constanta, pp.113-114, 2016.

12. Pantelica A., Frontasyeva M.V., Trinh M., Culicov O.A., Zinicovscaia I., Pantelica D., Apostol A., Ghita D.G, Comparison of ion beam analysis (IBA) and Instrumental Neutron Activation Analysis (INAA) techniques on tree leaves samples, 17th International Balkan Workshop on Applied Physics and Materials Science (IBWAP 2017), 11-14 July 2017, Constanta, Romania, Poster S3 P16, Book of Abstracts, Ovidius University Press, Constanta, 129, 2017.

13. Ene A., Improvement of sensitivity in PIGE analysis of steels by neutron-gamma coincidences measurement, Nuclear Instruments and Methods in Physics Research B222, 228-234, 2004.

14. Gomez S., Garcia A., Landete-Castillejos T., Gallego L., Pantelica D., Pantelica A., Preoteasa E.A., Scafes A. and Straticiuc M., Potential of the Bucharest 3 MV Tandetron ${ }^{\mathrm{TM}}$ for IBA studies of deer antler mineralization, Nuclear Instruments and Methods in Physics Research B371, 413-418, 2016.

15. Ene A., Pantelica A., Freitas M.C., Bosneaga A., EDXRF and INAA analysis of soils in the vicinity of a metallurgical plant, Rom. Journal Phys. 56 (7-8), 993-1000, 2011.

16. Pantelica A., Cercasov V., Steinnes E, Bode P., Wolterbeek H. Th., Determination of 54 Elements in Lichen Transplants: Comparison of INAA, ICPMS, and EDXRF, Rom. Journ. Phys. 61 (7-8), 1380-1388, 2016.

17. Balasoiu M., Kichanov S, Pantelica A., Pantelica D., Stolyar S., Iskhakov R., Aranghel D., Ionescu P., Badita C.R., Kurkin S., Orelovich O., Tiutiunikov S., Characterization of biogenic ferrihydrite nanoparticles by means of SAXS, SRD and IBA methods, Journal of Physics: Conference Series 994, 012012, 2018.

18. Moraru S.S., Ene A., Gosav S., Study of the correlativity between parameters and mineralogy of contaminated agricultural soils, ISI Proceedings of the 19th International Multidisciplinary Scientific GeoConference (SGEM 2019), 19 (3.2), 441-448, 2019, doi: 10.5593/ sgem2019/3.2/S13.058.

19. Moraru S.S., Ene A., Gosav S., Mineralogical composition assessment of soils from Covurlui and Braila Plains by ATR-FTIR Technique, Proceedings, 29 (1), 80, 2019. 